\title{
Accuracy vs. Precision: Understanding Potential Errors from Radiocarbon Dating on African Landscapes
}

\author{
David K. Wright (D)
}

Published online: 30 June 2017

(C) The Author(s) 2017. This article is an open access publication

\begin{abstract}
The application of radiocarbon dating to determine the geochronology of archaeological sites is ubiquitous across the African continent. Accelerator mass spectrometry has made radiocarbon dating the most precise method to determine the death of living organisms that occurred within the last 50,000 years. However, the method is not without limitations and this review article provides Africanist archaeologists with cautionary insights as to when, where, and how to utilize radiocarbon dates. Specifically, the review will concentrate on the potential of carbon reservoirs and recycled organic remains to inflate apparent age estimates, diagenesis of carbon isotopes in variable $\mathrm{pH}$ ecologies, and hot-humid climates and non-climate-controlled archives that can compromise the efficacy of samples. Legacy radiocarbon ages must be critically examined for what method was used to generate the age, and calibration radiocarbon ages from critical periods of African prehistory lack precision to resolve significant debates. A multipronged dating strategy and careful selection of radiocarbon sample materials are advocated from the earliest stages of research design.
\end{abstract}

Résumé L'application de la datation par le carbone 14 pour déterminer la géochronologie des sites archéologiques est. omniprésente à travers le continent africain. La spectrométrie de masse a rendu la datation

D. K. Wright $(\bowtie)$

Department of Archaeology and Art History, College of Humanities, 1 Gwanak-ro, Seoul 08826, South Korea e-mail: msafiri@snu.ac.kr par le carbone 14 la méthode la plus précise pour déterminer la mort d'organismes vivants ayant eux lieux au cours des 50,000 dernières années. Cependant, la méthode n'est. pas sans limites. Cette revue fournit les archéologues africanistes avec des appréciations et des mises en garde sur l'utilisation des âges radiocarbone. Plus précisément, cette revue se concentrera sur la possibilité que les estimations d'âge apparentes soient exagérées par la présence de réservoirs de carbone et de restes organiques recyclées, sur la diagenèse d'isotopes de carbone dans les écologies de $\mathrm{pH}$ variables, et sur les climats chauds et humides ainsi que les archives sans température contrôlée qui peuvent compromettre l'efficacité des échantillons. Les âges radiocarbone basés sur des données anciennes doivent être rigoureusement examinés pour en déduire la méthode employée dans la détermination d'âge. Egalement, les âges radiocarbone de calibration, issue de périodes critiques de la préhistoire africaine, manque la précision nécessaire pour résoudre des débats importants. Une stratégie de datation multiple et une sélection rigoureuse des matériaux d'échantillons de radiocarbone sont conseillées dès les premières étapes de la conception de la recherche.

Keywords Radiocarbon dating - African archaeology · Diagenesis · Carbon reservoir effect $\cdot$ Museum archival research · Taphonomy

Radiocarbon dating is the most frequently utilized method for gaining geochronology on archaeological sites across the world. The general reliability of the method 
and abundance of sites with carbon-based materials for dating have justifiably propelled radiocarbon dating to the top of the available methods for securing age control on archaeological activity. According to the University of Arizona, the publishers of Radiocarbon journal, as of September 2016, there were 152 active radiocarbon labs in 50 countries (http://www.radiocarbon.org/Info/Labs. pdf). This gives consumers of radiocarbon services a wide range of choices in where and how to obtain a radiocarbon chronology.

Overall, it is difficult to argue for a downside to the increased availability and applicability of radiocarbon dating, but it is important for archaeologists to handle their prime tool for dating site occupations with great care. There are two interrelated concepts with any form of radiometric dating: accuracy and precision. Accuracy refers to how close the assessed age of a sample is to the true age. Precision refers to the statistical uncertainty associated with an age estimate- the greater the precision, the less uncertainty there is in the assessed age. However, a precise estimate of the age of an artifact (e.g., 10,000 \pm 10 years before present [BP]) is worthless if the sample is contaminated or has moved from its primary context, compromising its accuracy.

This review article will focus specifically on potential sources of error and critical evaluation of radiocarbon dates from the perspective of conducting research on the African continent. Like all continents, Africa has a heterogeneous geography and should not be viewed as a single "place." However, in the context of this review, it will become obvious that there are issues unique to radiocarbon dating in Africa that overlap other areas of the world, but combine to create circumstances specific to the continent given the history of research conducted therein. Interested readers are urged to read more general reviews of radiocarbon dating, which discuss issues more exhaustively and globally (e.g., Bronk Ramsey 2008; Jull et al. 2013; Rapp and Hill 2006; Taylor and Bar-Yosef 2014; Waters 1998).

This review will begin generally to explain the process of radiocarbon production in the atmosphere, and how three isotopes of carbon become associated with all living organisms that eventually die and find their way into the archaeologist's sample collection. Six issues will then be brought into focus facing archaeologists working in Africa that may not be common knowledge: (1) dating ostrich (Struthio camelus) eggshell and mollusk shells must be approached with caution; (2) wood charcoal from certain species of long-lived trees such as baobabs
(Adansonia sp.) can provide overestimates of ages on the order of hundreds of years; (3) diagenetic changes in bone chemistry within archaeological contexts in hot and/or humid climates of Africa confound accurate ${ }^{14} \mathrm{C}$ age estimations in many contexts; (4) nonclimate controlled archival storage of archaeological collections can promote the growth of microorganisms on artifacts, which can contribute to the datable carbon fraction; (5) legacy data may have been subject to systematic errors in processing and analyzing samples; and (6) wiggles and flatlines in the atmospheric concentrations of ${ }^{14} \mathrm{C}$ occur at particularly hallmark time periods in the cultural evolution of the African continent, such that the most recent calibration curve (presently Reimer et al. 2013) must be used for all ages being published. A multipronged approach to dating must be integrated from the outset of archaeological investigation (namely, during the grantwriting process).

\section{General Background: From Whence Cometh My Radiocarbon Date?}

It is safe to assume that all professional archaeologists are generally aware of the radiocarbon dating technique, that it can be performed on carbon recovered in archaeological deposits, and handling datable materials is best done with relative care to avoid contaminating the materials with finger oils, cigarette ashes, or other environmental contaminants found on archaeological sites. However, my own experience indicates that there is a lack of understanding of what, specifically, is being measured from samples; what is involved in the atmosphere-to-biosphere production, retention, and decay of radiocarbon; and what should and should not be dated from archaeological deposits using radiocarbon dating techniques. Therefore, I will introduce the topic with a brief summary suitable for advanced students and archaeological professionals.

Radiocarbon $\left({ }^{14} \mathrm{C}\right)$ is an unstable isotope of carbon produced in the atmosphere and troposphere of Earth as cosmic rays collide with ${ }^{14} \mathrm{~N}$ (Fig. 1). The radioactive ${ }^{14} \mathrm{C}$ binds with oxygen to become $\mathrm{CO}_{2}$. Living organisms uptake and metabolize all forms of carbon from Earth's carbon reservoir, within which carbon cycles between the troposphere, atmosphere, hydrosphere, lithosphere, and biosphere. The stable isotopes of ${ }^{12} \mathrm{C}$ and ${ }^{13} \mathrm{C}$ are more naturally abundant and therefore occur in higher quantities in these organisms. The ratio of ${ }^{12} \mathrm{C}$ 


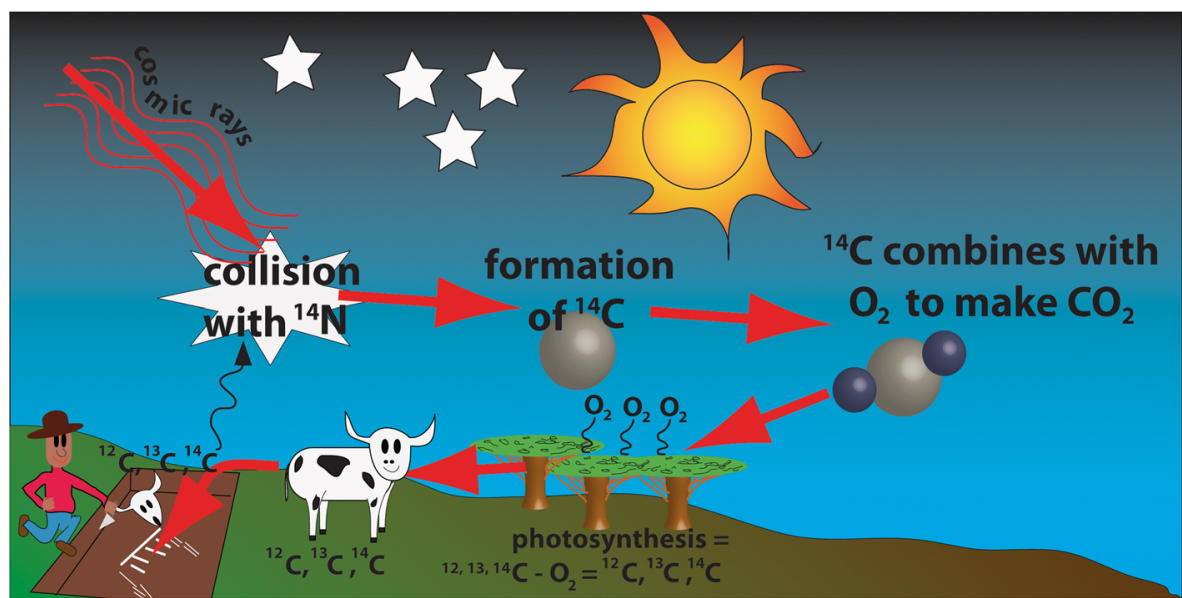

Fig. 1 Production, consumption, and recycling of ${ }^{14} \mathrm{C}$ in the atmosphere and biosphere (images in full color online)

and ${ }^{13} \mathrm{C}$ is proportional at $99: 1 .{ }^{12} \mathrm{C}$ isotopes are proportional to ${ }^{14} \mathrm{C}$ isotopes at a ratio of approximately $10^{12}: 1$ (Taylor and Bar-Yosef 2014). Upon death of any living organism, the ${ }^{14} \mathrm{C}$ decays with a half-life of 5,730 years on its way back to becoming ${ }^{14} \mathrm{~N}$, while the amount of ${ }^{13} \mathrm{C}$ remains constant (assuming there are no external factors that affect this process, but see discussion below). After approximately 50,000 years, there is almost no amount of detectable ${ }^{14} \mathrm{C}$ remaining in most carbonbased organisms, and this is typically considered the upper limit of what can be dated using the ${ }^{14} \mathrm{C}$ method.

The first application for measuring radiocarbon in the laboratory was developed by Willard Libby in 1949 using a screen-walled counter, which is similar to a modified Geiger counter, to detect emission of beta particles. Beta particles are electrons or positrons that are emitted from the nucleus of an atom during the process of radioactive decay. Gas proportional counting was developed later, involving the combustion of organic matter into methane $\left(\mathrm{CH}_{4}\right)$, from which beta particles were counted during radioactive decay of ${ }^{14} \mathrm{C}$ (Kromer and Münnich 1992). Later, the method of liquid scintillation was developed in which carbon was converted into benzene $\left(\mathrm{C}_{6} \mathrm{H}_{6}\right)$, and a scintillator counted beta decay in a photomultiplier tube (Arnold 1954; Polach 1987). By the late 1970s, the use of accelerator mass spectromettry (AMS) began gaining favor as a method for precisely counting carbon isotopes, following the production of catalytically condensed graphitic carbon (CCGC) from $\mathrm{CO}_{2}$ (Taylor and Bar-Yosef 2014). When the CCGC is bombarded with cesium ions, negative carbon $(\mathrm{C}-)$ ions are extracted into the accelerator beam line that terminates in a particle detector in which ${ }^{12} \mathrm{C}$,
${ }^{13} \mathrm{C}$, and ${ }^{14} \mathrm{C}$ isotopes can be counted. Pee Dee Belemnite (PDB) is a Cretaceous marine fossil (Belemnitella americana) from South Carolina, which is used as the standard measure of the ratio of ${ }^{13} \mathrm{C}$ relative to ${ }^{12} \mathrm{C}$ in gas-source mass spectrometers. The ratio of ${ }^{14} \mathrm{C}$ vs. ${ }^{12} \mathrm{C}$ is calibrated using the National Institute for Standards and Technology (NIST) oxalic acid $\left(\mathrm{H}_{2} \mathrm{C}_{2} \mathrm{O}_{4}\right)$ standard.

Generally, the half-life model structured into ${ }^{14} \mathrm{C}$ dating assumes that the production of ${ }^{14} \mathrm{C}$ in the atmosphere has been constant through time; however, it is now well known that ${ }^{14} \mathrm{C}$ concentrations have been variable. Therefore, radiocarbon ages must be calibrated to accommodate these inconsistencies, which relate to the uptake of relative proportions of ${ }^{12} \mathrm{C},{ }^{13} \mathrm{C}$, and ${ }^{14} \mathrm{C}$ by living organisms out of the dynamic carbon reservoir over time (e.g., Reimer et al. 2013). Near the advent of the Industrial Revolution (after AD 1620), atmospheric concentrations of carbon diluted the ${ }^{14} \mathrm{C}$ in the atmosphere, making dating imprecise. This is called the Suess Effect (Keeling 1979). The detonation of nuclear weapons in the 1940 s added massive quantities of ${ }^{14} \mathrm{C}$ to the atmosphere, which is called the Libby Effect. It is now possible to obtain an accurate and precise radiocarbon date from the Libby Effect era, due to reduced (but still elevated) concentrations in atmospheric ${ }^{14} \mathrm{C}$ following adoption of the Nuclear Test Ban Treaty of 1963 (Reimer et al. 2004b). Online software applications such as CALIB (http://calib.qub.ac.uk) and OxCal (https://c14.arch.ox.ac.uk) can be used to calibrate ${ }^{14} \mathrm{C}$ ages.

This review will consider aspects of the production of ${ }^{14} \mathrm{C}$ in the atmosphere and troposphere, the life cycle, and postmortem diagenesis of certain 
organisms as they relate to uptake of carbon molecules, the way to evaluate legacy (archival) radiocarbon ages and the significance of calibration as it relates to specific events in African prehistory. All archaeologists should be aware of the fact that they are dating organic samples, and it is the archaeological context of that sample that determines its relationship to the site's age. If the contextual association of the sample to the site is poor or if there are taphonomic effects that have compromised the sample's integrity, the accuracy of the date relative to the archaeological occupation will be poor, even if the date is precise (e.g., \pm 10 years). The factors discussed below are challenges of which all Africanists must be keenly aware, but there are additional considerations that are more generally applicable, yet no less relevant (e.g., Bayliss 2009; Boaretto 2009; Higham 2011).

\section{Definitions of Effects on the Accuracy of Radiocarbon Dates}

Although this paper focuses specifically on factors that compromise radiocarbon dates on the African continent, a set of terms and conditions should be first briefly outlined.

\section{Diagenesis}

Diagenesis is a process in which the chemical components of a substance are altered from their primary states. As it applies to radiocarbon dating, diagenesis compromises carbon isotopes as (usually bone) tissues of the decomposing organisms interact with fluids present in soil (Hedges 2002). External effects such as $\mathrm{pH}$, temperature, and the microbial environment can amplify diagenesis while internal factors such as the crystal size, porosity, and solubility of the material also play a role (Zazzo and Saliège 2011). Simply put, diagenesis causes chemical changes to a sample due to geological or biological weathering processes exerted on the sample. The effect of this process can alter the $99{ }^{12} \mathrm{C}: 1{ }^{13} \mathrm{C}: 10^{-10}$ ${ }^{14} \mathrm{C}$ ratio presumed in radiocarbon dating. Diagenesis can be initiated during burial, excavation, transport, or curation of an artifact, and so it is a problem that must be considered by archaeologists intending to use radiocarbon as a dating tool.

\section{Reservoir and Hard Water Effects}

Reservoir effects occur when soluble inorganic carbon, which is devoid or has depleted quantities of ${ }^{14} \mathrm{C}$, is included in the calculation of the organic carbon isotopic fraction. Every living organism is part of the carbon reservoir as it absorbs atmospheric carbon through respiration or metabolizes it after consuming other carbonbased life forms. Because the atmospheric concentrations of carbon have varied over time, calibration corrects for variability of ${ }^{14} \mathrm{C}$ in the dynamic reservoir, but what if the object being dated includes carbon that is not part of the dynamic reservoir?

In general, plants and animals that spend their lives submerged underwater are subject to reservoir effects due to the presence of ${ }^{14} \mathrm{C}$-depleted carbon that is ingested and incorporated into skeletal structures. In aqueous environments, old carbon is recycled in a process called the "hard water effect," in which inorganic $(\mathrm{Ca}-, \mathrm{Mg}-)$ carbonate is retained in the water column. Aquatic flora and fauna do not discriminate between inorganic and organic carbon when they ingest and metabolize food. Thus, seeds and skeletons from aquatic organisms should be separated from terrestrial species prior to dating, because carbon fractionation in water-borne samples will potentially include a carbon reservoir effect from inorganic carbonate consumption (Aravena et al. 1992; Marty and Myrbo 2014; Philippsen 2013). Additionally, bones from people who had strongly aquatic-based diets have been shown to have reservoir effects of hundreds or even thousands of years (Cook et al. 2002; Cook et al. 2001; Olsen et al. 2010; Schmidt 2000). Reservoir effects can often be corrected, but labs must be made aware of this possibility upfront. The most efficient means of testing for a carbon reservoir effect is to collect samples suspected of having those effects, and compare their ${ }^{14} \mathrm{C}$ values with those from stratigraphically associated samples, assumed to have metabolized only dynamic carbon during its lifetime (sensu Cohen et al. 1997).

\section{Old Wood}

"Old wood" is a problem that occurs when wood from semiarid and arid regions is curated through multiple generations or from sampling biases that can occur from long-lived tree species. Because radiocarbon dating measures the time when an organism ceases to uptake and metabolize dynamic carbon, if a house post is used for 500 years, then the date of that artifact will not reflect 
the disuse of that object in the archaeological record. Similarly, if a tree is a thousand years old, the inner growth rings will reflect a radiocarbon age that is much older than the outermost growth rings. Michael Schiffer $(1982,1986)$ first described this problem in the context of the American Southwest, where posts for constructing pit houses are heirlooms due to the exceeding rareness of wood in desert environments. There are many ways, however, in which wood and charcoal can be curated and recycled by humans over generations.

\section{Dolomitization and Recrystallization}

Dolomitization is a diagenetic process that involves the replacement of calcium $(\mathrm{Ca})$ ions with magnesium $(\mathrm{Mg})$ ions in calcite and aragonite. Calcite comprises the primary inorganic constituent in avian eggshells (Driessens and Verbeeck 1990). Soil carbonates are also affected by dolomitization, depending on the prevailing climate, degree of water saturation, and permeability of the calcareous nodules (Chen and Polach 1986; Hird and Tucker 1988; Swart et al. 1989). Generally, dolomitization affects oolites and carbonate nodules by recrystallizing the outer surfaces, leaving the inner surfaces intact. A similar process occurs in mollusk shells when aragonite is dissolved and recrystallized into calcite (Goslar and Pazdur 1985; Yates et al. 2002). Radiocarbon ages of recrystallized nodules tend to show younger ages on the reprecipitated surfaces, with older ages on the nonaffected surfaces. This is because the quantities of inorganic ${ }^{13} \mathrm{C}$ are artificially lower with respect to the organic (includes ${ }^{14} \mathrm{C}$ ) constituents due to loss of carbon in the older portions of the nodules (Amundson et al. 1994; Chappell and Polach 1972; Chen and Polach 1986; Zamanian et al. 2016). Whether (re)precipitates are older or younger than the non- or primary precipitates in a sample depends on parent material weathering, and whether the precipitates are authigenic (formed in situ) or allogenic (formed ex situ) in origin.

\section{Legacy Data}

Legacy data consist of radiocarbon ages that were generated prior to systematic efforts to standardize laboratory preparation, measurement, and reporting practices. Many archaeologists incorporate archaeological data that involved conventional bulk counting analytical procedures prior to the widespread use of AMS. Counting using liquid or gas scintillation techniques necessitates low or controlled background radiation (Wagner 1998), which was not as precisely constrained in previous decades as today's laboratory scintillation protocols require (Lehto and Hou 2011). More presciently, poor results of the first interlaboratory comparison (International Study Group 1982) were attributed to nonsystematic sample standard treatments (Kazimierz et al. 1992). The retraction of 470 radiocarbon dates by the British Museum radiocarbon laboratory between 1980 and 1984 is an extreme case where laboratory handling procedures were blamed for the introduction of systematic errors in the results that were generated (Ambers et al. 1986; Bowman et al. 1990). To improve the quality and accuracy of radiocarbon dating following the first intercomparative study, successive series of comparative analyses of results (SIRI, TIRI, FIRI, VIRI) were performed by voluntary and anonymous participation of laboratories around the world (for histories of the analyses, see Scott et al. 2003; Scott et al. 2010).

Improvements in materials and laboratory protocols over the last 60 years have increased both the accuracy and the precision of radiocarbon dates, so legacy data must be treated carefully with the understanding that older technologies may have produced spurious or at least imprecise results. The widespread use of lithium counting rods, which emit acetylene $\left(\mathrm{C}_{2} \mathrm{H}_{2}\right)$ when heated, in the scintillation process before 1990 resulted in systemic errors on the order of hundreds of years (Geyh 1990), though these are difficult to assess without testing unspent samples from the same lot. The problem was discovered during the International Study Group measurement of accuracy using German oak logs (Geyh 1990). Labs using benzene $\left(\mathrm{C}_{6} \mathrm{H}_{6}\right)$ for counting were not subject to this particular error. Polach (1992) outlines dozens of protocols that were developed for liquid scintillation based on systematic errors discovered since the introduction of commercial counters in 1953.

\section{Specific Applications of These Effects on Radiocarbon Dates in African Archaeology}

\section{Ostrich Eggshell}

Ostrich eggshell (OES) is commonly subject to radiocarbon dating in the African context. There is a relative abundance of OES in archaeological deposits after 40,000 years ago, it is quite durable as a material, it 
does not decompose as easily as bone, and most labs have no trouble processing samples into graphite or benzene (Bird et al. 2003; Freundlich et al. 1989; Vogel et al. 2001). However, there are peculiar taphonomic effects associated with ostrich eggs exposed to variable-pH geological settings that warrant consideration before one obtains ${ }^{14} \mathrm{C}$ ages from their shells.

The porous nature of OES can allow for some absorption of groundwater and recrystallization of portions of the calcitic palisade layer via dolomitization if the outer surface of the shell acidifies (Fig. 2). Documentation of dolomitization and its potential effect on biomineral formation processes in ancient OES is limited to a single study. Ratite shells from India thought to date to the Late Pleistocene yielded evidence of diagenetic dolomite using Electron Backscatter Diffraction (Jain et al. 2016). The distribution of diagenetic dolomite relative to calcite was detected irregularly throughout the tested eggshells, although higher concentrations of dolomite were generally found closer to the outer surfaces (Jain et al. 2016). The broader ecological and sedimentary conditions under which dolomitization within ratite shells occurs are unclear, but the shells tested by Jain et al. (2016) were recovered in the Rajasthan and Gujarat states of northern India, which are located within tropical arid to semiarid climate zones influenced by annual monsoons.

Depending on the geochemical environment, dolomitization or other authigenic mineralization processes potentially can affect the palisade layer of OES, enriching ${ }^{13} \mathrm{C}$ values and producing anomalously old radiocarbon ages. Some measure of chemical degradation to the outer surface of the OES would need to occur to expose the inner layers to diagenesis. However, given sufficiently acidic soil conditions and ample exposure to moisture, there is nothing about the chemical structure of OES that would preclude dolomitization of calcites.

Other diagenetic effects can occur in OES. An initial study of the potential for "old carbon" in samples determined that there was an average overestimate of $350 \pm 60$ years when comparing OES to charcoal or bone recovered from the same archaeological context from mid-Holocene sites in northern Africa (Freundlich et al. 1989). Vogel et al. (2001) studied the potential for diagenesis using paired charcoal and OES from northern and southern African sites, and determined a $2.2 \%$ deficit in ${ }^{14} \mathrm{C}$ in OES relative to atmospheric ${ }^{14} \mathrm{C}$ due to fossil carbon inclusions in the carbonate fraction of the eggshell. A recent study confirmed the apparent reservoir effect by comparing AMS ages from OES and pottery with luminescence ages on pottery from Bronze Age sites in the Gobi Desert, Northeast Asia (Janz et al. 2015). AMS ages on OES were significantly older in all cases relative to the pottery ages, and in most cases, implausibly old by thousands or tens of thousands of years (Janz et al. 2015). It is conceivable that the OES could have been curated or recycled in bead manufacturing (see below), but it is also possible that bedrock geology can play a key role in the diagenetic processes that affect mineralization in a ratite's eggshell. Therefore, it is critical for all researchers to consider the potential for postdepositional diagenesis in OES located in limestone basement systems or areas with low or variable soil $\mathrm{pH}$ conditions, which may reflect high concentrations of surface carbonates (Fig. 3).

\section{Mollusks}

In addition to diagenetic effects, metabolic pathways of living organisms must be considered when obtaining
Fig. 2 Schematic and photographed profile view of ostrich eggshell adapted from Jain et al. (2016). Photographed thin section of ostrich eggshell (left) in plane-polarized light from Hoedjiespunt, South Africa was provided by Christopher Miller at the Eberhard-Karls-Universität Tübingen, Institut für Naturwissenschaftliche Archäologie

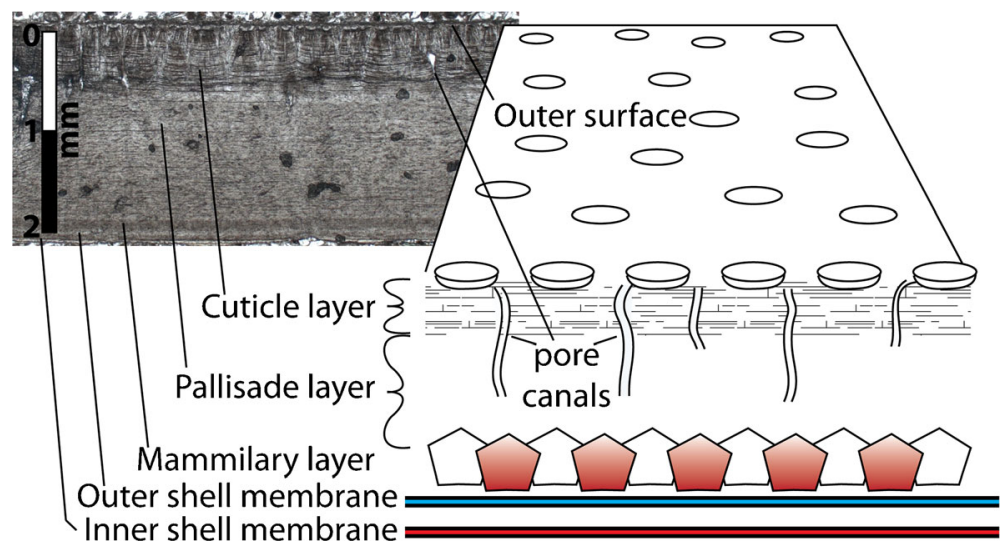




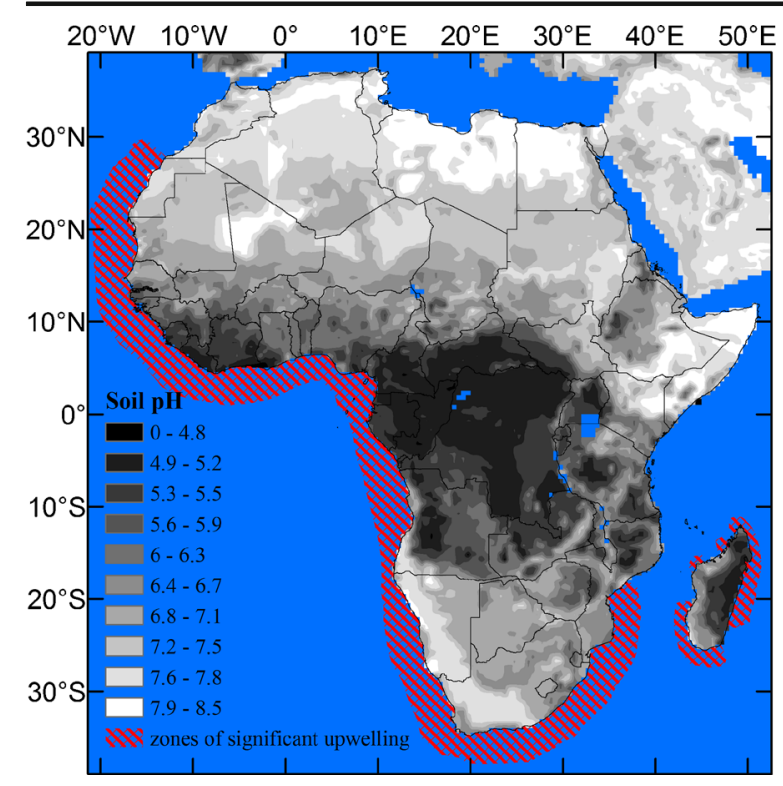

Fig. 3 General map of soil $\mathrm{pH}$ conditions across Africa (IGBPDIS 1998) using natural Jenks classifications in ArcGIS 10.2.2. Generally, high $\mathrm{pH}$ regions would have a higher potential for inducing dolomitization in ostrich eggshell and carbon reservoir effects in mollusk shells compared to low $\mathrm{pH}$ regions. High $\mathrm{pH}$ areas will typically have higher potential for bone diagenesis. Also shown are coastal upwelling zones delineated by the National Oceanic Atmospheric Administration (2016)

radiocarbon ages. Organisms that create chitin $\left(\left[\mathrm{C}_{8} \mathrm{H}_{13} \mathrm{O}_{5} \mathrm{~N}\right]_{n}\right)$-based exoskeletons, such as beetles, or calcium carbonate $\left(\mathrm{CaCO}_{3}\right)$-based shells, such as terrestrial mollusks, can metabolically recycle ${ }^{14} \mathrm{C}$-depleted carbon from bedrock as they synthesize bicarbonate for skeletal production (Rick et al. 2005). Vast tracts of the Sahara and southern Africa are particularly susceptible to reservoir effects, because the bedrock is primarily made of limestone and shale. For example, studies from the eastern Sahara have detected offsets between organic muds and carbonates of 600 to 1,000 years, due to the reservoir effect on carbonates (Haynes et al. 1989; Pachur and Hoelzmann 2000). On the other hand, in a study of potential reservoir carbon in ostracodes from Lake Turkana, Halfman et al. (1992, 1994) determine negligible carbon reservoir effects when compared to carbonate and magnetic susceptibility dates. Paired freshwater mollusk and optically stimulated luminescence (OSL) ages from Lake Turkana also determined no detectable reservoir effect (Forman et al. 2014), but the majority of the bedrock of this basin consists of Tertiary mafic volcanics and Precambrian gneisses and schists, which are low in carbon.
Coastal zones in many portions of Africa are subject to upwelling of marine currents (Fig. 3) that potentially enhance marine reservoir effects on mollusks (e.g., Bateman et al. 2008; Dewar et al. 2012; Mollenhauer et al. 2007; Wündsch et al. 2016). Upwelling brings organic nutrients and inorganic carbon from the deep ocean floor to the near surface environment where marine mollusks live and feed. Ultimately, they use those minerals to construct their shells. Marine mollusks were important sources of food for past people living in coastal regions, and therefore have great potential to provide a chronology of past human activities. However, if marine mollusks are to be used for radiocarbon dating, specific marine reservoir corrections should be made through online databases such as OxCal and CALIB. Marine reservoir corrections are currently constructed from regional databases, which augment the global marine reservoir correction architecture originally presented in Reimer et al. (2004a). Geographic gaps in the effectiveness of the marine reservoir correction persist (Hua et al. 2015; Jull et al. 2013; Reimer et al. 2013). Prior to radiocarbon dating marine mollusks from a specific project area, it is advisable to investigate whether a robust marine reservoir correction $(\Delta R)$ is available.

\section{Old Wood}

Africa is subject to similar wood scarcities as the American Southwest due to the large proportion of the continent that falls within arid and semiarid climatic zones (Fig. 4). To complicate matters, many of the now hyperarid regions of Africa were once woodland environments (deMenocal et al. 2000; Gasse 2000; Thomas and Burrough 2012). As the climate shifted from pluvial to arid between 8,000 and 5,000 years ago, woodlands turned to open desert, but the relicts were left on the landscape.

A similar effect was considered when dating a copper-smelting furnace in the Agadez region of Niger, questioning the validity of the radiocarbon dates on the basis that there is a high potential that the charcoal used to smelt the metal was naturally burned some time before use in metal smelting (Killick et al. 1988). The interpretation is that the charcoal formed from a natural forest fire, which smoldered the roots of the trees in situ, turning them to charcoal. Erosion later exposed the charcoal, which was opportunistically used by ironsmiths for forging. Similarly, Clist (2012) questions 
a 4,000- to 4,500-year-old iron forge identified by Zangato and Holl (2010) at Ôboui, Central African Republic on the basis that the charcoal was likely excavated out of the subsoil when structures were being constructed, then used in iron production.

The old wood phenomenon can also apply to wood that has not been curated or recycled, but derives from a long-lived species. A study sampling wood from different aspects of a baobab tree with false cavities from Mozambique reveals that extant portions of the tree can be $>1,300$ years old (Patrut et al. 2011; Patrut et al. 2015). The study showed that single baobab trees can yield radiocarbon ages separated by hundreds of years, depending on the aspect of the tree that is sampled. The troubling portion of this study for archaeologists was that the oldest aspects of the trees were those located adjacent to the cavity bark, which the ethnographic record shows is a preferred location for manufacturing artifacts such as rope, baskets, mats, cloth, toys, games, and even weapons (De Caluwé et al. 2009; Nkana and Iddi 1991; Schumann et al. 2012; Woodburn 1970).

\section{Special Artifacts}

A related issue pertains to the curation of jewelry made out of OES beads and cowrie shells, and wooden artifacts like headrests. These artifacts can be passed down intergenerationally and traded as prestige items across time and space. Hodder (1977) identifies this phenomenon in the Lake Baringo area of Kenya. In his ethnographic account, artifacts move in prescribed directions, whereas some artifacts are created and never move out of their home area. Wooden artifacts were also highly sought after in the West African trans-Saharan exchange network, transported hundreds of kilometers to their end destinations, and highly prized and conserved as a result (Lawal 1973; Stoller 2003). In the end, it becomes difficult for archaeologists to interpret whether the bits of preserved organic remains are those from a stool that has been conserved for multiple generations, or were buried a short time after the accumulation of carbon ceased in the organism from which the artifact was derived.

\section{Bone Diagenesis}

As outlined above, following death of an organism, the assumption of radiocarbon dating is that ${ }^{14} \mathrm{C}$ decays in half-lives while ${ }^{12} \mathrm{C}$ and ${ }^{13} \mathrm{C}$ remain at constant levels. However, in hot and humid environments, which are common in Africa (Fig. 4), decay in bone material can involve the exchange of soil-derived amino acids between the environment and artifact (Hedges 2002; LeeThorp 2008; López-Costas et al. 2016). In addition to the OES, bone apatite is particularly susceptible to postmortem carbon molecule exchange, and is no longer widely used for dating purposes without clear evidence for a lack of diagenetic effects. In the arid regions of Africa, it has been demonstrated that biological apatites can be dated successfully because there are fewer diagenetic-inducing microbes relative to humid ecosystems (Zazzo 2014; Zazzo and Saliège 2011), but generally, protein collagen is preferred for ${ }^{14} \mathrm{C}$ dating. However, leaching of carbon and microbial attack on collagen can also be acute in tropical ecosystems particularly if the artifact is not rapidly buried (Jans 2008). There is nothing to exclude postdepositional diagenetic changes in plant macrofossils as well, particularly on the outer portions of the stalk or seed. Many of these effects are now controlled by laboratories that assay carbon isotopes by performing alternating acid and alkali washes to remove diagenetic contaminates such as groundwater carbonates and sedimentary carbon; ultrafiltration is also used to concentrate the high-molecular weight material (Ambrose 1990; Brock et al. 2010; Higham et al. 2006).

The best way to isolate diagenetic effects on bone is by conducting experimental archaeology on samples whose taphonomy is well understood. A study of bone diagenesis from modern samples, collected from the ground surface in Amboseli National Park, showed significant reprecipitation and mineralization of bone within 40 years following death of the organism (Trueman et al. 2004). A study conducted on 58 skeletal samples from a single cemetery near Khartoum, Sudan found significantly more bone diagenesis from individuals buried during wetter climatic conditions than during drier conditions (Dal Sasso et al. 2014). A similar study found that contemporary burials from Dhar Oualata and Néma in Mauritania and Daounas in Mali exhibited different degrees of bone diagenesis depending on the local hydrological conditions; bone was substantially more diagenetically altered at the site with occasional flooding than at the site in the drier setting (Maurer et al. 2014). Fourier transform infrared spectroscopy (FTIR) or scanning electron microscopy (SEM) are excellent tools to determine the degree of diagenesis on bone before undertaking ${ }^{14} \mathrm{C}$ dating or other stable carbon isotope analyses (e.g., D’Elia et al. 2007; 


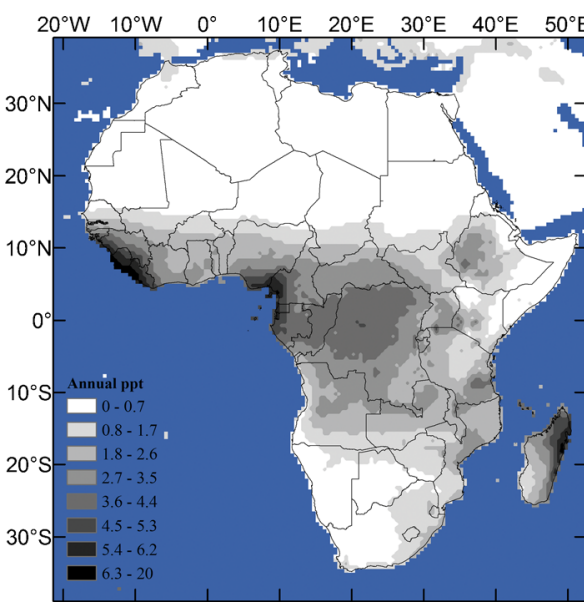

Fig. 4 Left: Map of Africa showing mean annual precipitation that falls on a grid cell in units of millimeters $\left(\mathrm{mm}^{3}\right.$ per year $/ \mathrm{mm}^{2}=\mathrm{mm} /$ year) separated by natural Jenks using ArcGIS 10.2.2 (University of East Anglia 2016). Right: Normalized and averaged raster map of precipitation and temperature (raw data acquired from University of East Anglia 2016) on a scale of 0 to 1.

Hollund et al. 2013; Lebon et al. 2010; Snoeck et al. 2014). More commonly, experiments to evaluate the ratio of carbon to nitrogen $(\mathrm{C} / \mathrm{N})$ within bone can determine with $71 \%$ accuracy whether or not collagen from the samples have undergone postmortem degradation (Brock et al. 2012; van Klinken 1999). Although time-consuming and expensive, these analyses can yield dividends, because if a bone sample has been adversely impacted by diagenesis, a diagenetically resistant amino acid called hydroxyproline $\left(\mathrm{C}_{5} \mathrm{H}_{9} \mathrm{NO}_{3}\right)$ can be reliably ${ }^{14} \mathrm{C}$ dated from the bones of most large mammals (Marom et al. 2013).

\section{Artifact Storage}

Following a field season, most artifacts are curated in repositories and dating of artifacts can take place years or decades after the project concludes. Across the tropics, heat and humidity present challenges to the longterm efficacy of carbon-based artifacts, because this is an environment that is conducive to the growth of bacteria and other microorganisms. This phenomenon was originally identified from varved clays from an archival collection in Sweden, in which the samples that had been curated the longest produced anomalously young ages (Wohlfarth et al. 1998). Fungi and other microorganisms grow during storage, particularly on samples that were wet or are stored in cool and humid conditions. As they attack the samples, microbes isotopically exchange carbon with the artifact, which is

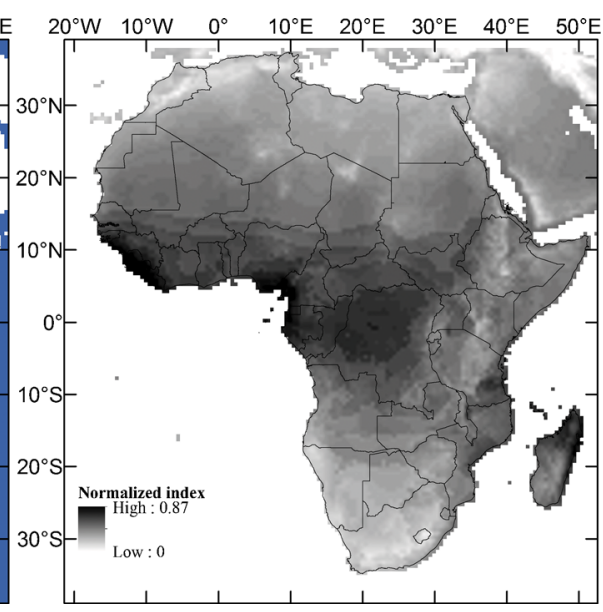

Zero represents the coolest and driest average aggregated conditions between the years 1961 and 1990, while 0.87 represents the hottest and wettest averaged aggregated conditions for the same time period. Generally, lighter shaded regions have high potential for recycling of "old wood" while darker areas are likely to have high rates of organic decomposition

incorporated into the sample affecting the ultimate estimate of the modern fraction of carbon in the sample. Typically, this will result in a lower age estimate than the result would have been if the sample had not been stored for some period.

Similarly, certain common protocols in handling and storing artifacts can compromise the $\delta^{13} \mathrm{C}$ by up to $1.5 \%$ o. Experiments on loess soils showed that heating above $60{ }^{\circ} \mathrm{C}$, storage in wet conditions, and freezing samples followed by freeze drying significantly altered the isotopes measured compared with the same samples that had not undergone these processes (Gauthier and Hatté 2008). Microbial growth from the cold storage of pollen is also suspected as denigrating the integrity of $\delta^{13} \mathrm{C}$ from sediment core samples (Neulieb et al. 2013).

Many African museums lack rigorous climate controlled conditions due to chronic shortages in power, lack of investment in climate control, and, even if climate control systems were installed, the original taphonomy of the samples themselves prior to collection would have instigated microbe growth once the sample was exposed to hot and humid air during excavation. Systematic tests on how microbes potentially affect sample efficacy from nonclimate controlled environments have not been undertaken. However, one test was performed on a sample collected from an archaeological site excavated from western Lake Turkana, Kenya in 1980. A notecard in the National Museums of Kenya, Nairobi collections indicated that the site had a radiocarbon age 
from charcoal of 3,370 \pm 190 years BP, but no additional information was provided. Charcoal was taken from the bag and submitted to the AMS facility at Seoul National University for ${ }^{14} \mathrm{C}$ dating in 2013 . The resulting ${ }^{14} \mathrm{C}$ age was 3,160 \pm 40 years BP (Table 1). Subsequently, additional notes for the original ${ }^{14} \mathrm{C}$ age were located indicating that the sample was generated at Geochron Laboratories. Unfortunately, $\delta^{13} \mathrm{C}$ are not available for GX8747 (Robert Yriart, personal communication, February 26,2016 ), so it is impossible to determine whether diagenesis may have affected the ultimate $\delta^{13} \mathrm{C} \%$ o assayed from the sample. However, the results indicate that the uncalibrated ${ }^{14} \mathrm{C}$ ages overlap within $1 \sigma$. Given the inherent statistical uncertainties associated with scintillation techniques used before the 1980s, comparing $\delta^{13} \mathrm{C}$ values from non-AMS-generated samples to those generated using AMS will likely not demonstrate any significant statistical difference. However, it should be assumed that if a sample has sat on a storage shelf for some period of time, microbial-induced diagenesis may have degraded the integrity of the sample. To avoid or minimize such effects, thorough drying of samples prior to storage will inhibit fungal and bacterial growth. Lowtech options such as using hairdryers or air-drying samples in the sun are better than doing nothing at all.

\section{Legacy Dates}

Due to its recognized centrality in the story of the origins of humanity, Africa was subject to intensive archaeological investigation in the early days of radiocarbon dating. However, many of the radiocarbon ages generated prior to the 1990s must be critically assessed. Although many labs were calculating stable isotope ratios between ${ }^{12} \mathrm{C} /{ }^{13} \mathrm{C}$ by the 1970 s (Stuiver and Polach 1977), such calculations were not commonly performed before the 1990s (Taylor and Bar-Yosef 2014). Therefore, corrections for isotopic fractionation cannot be made from those labs that did not do so. In Africa, where $\mathrm{C} 4$ grasses comprise a large proportion of the landscape (Ambrose and DeNiro 1986a, 1986b; Ambrose and Krigbaum 2003), understanding the photosynthetic pathways of ${ }^{13} \mathrm{C}$ retention in organisms is of critical importance in order to obtain an accurate radiocarbon date (e.g., Creel and Long 1986).

Compounding the problem for with using legacy data is the fact that as radiocarbon labs enter and leave the marketplace, curation of their records is not always centralized. The journals Archaeometry and Radiocarbon published the results of radiocarbon tests, until this practice was phased out in the 1990s and 2000s due to the sheer volume of measurements being processed by labs. The Journal of African History also published comprehensive lists of all radiocarbon dates from the entirety of the African continent until 1969 and increasingly selective portions of the continent until 2005 (e.g., Close 1988; Mitchell and Whitelaw 2005; Sinclair 1991), but this practice has been abandoned. Regional public databases have been assembled such as the Canadian Archaeological Radiocarbon Database (CARD), which also hosts many dates from eastern Africa (Courtney Mustaphi and Marchant 2016). However, the reality is that obtaining legacy dates and verifying their accuracy require legwork and knowledge of what separates a good date from a bad one.

A specific example of how changing standards of what is and is not datable have impacted understandings of African prehistory can be found in the Pastoral Neolithic. Many early dates were generated from bone apatite (Phillipson 2005; Sinclair 1991), which has been demonstrated as providing inaccurate radiocarbon dates in nonarid environments due to molecular exchange and fixation of carbonates from the environment to the apatite (Stafford et al. 1987; Taylor 1992). Critical reanalysis of regional datasets of early food producers has considered the impacts of bone apatite dates on developing regional chronologies (e.g., Ambrose 1998; Bower 1991; Collett and Robertshaw 1983; Wright et al. 2015).

Table 1 Radiocarbon ages generated from archival material analyzed from western Turkana

\begin{tabular}{llllll}
\hline Sample no. & Site & Material & $\delta^{13} \mathrm{C} \%$ o & ${ }^{14} \mathrm{C}$ age BP & Cal. age BP \\
\hline GX-8747 & FwJh16A & Charcoal & Unknown & $3370 \pm 190$ & $3160-4150$ \\
SNU13-390 & FwJh16A & Charcoal & -25.32 & $3160 \pm 40$ & $3250-3460$ \\
\hline
\end{tabular}

All ages were calibrated using version 7.1 of CALIB online software (http://calib.qub.ac.uk/calib/) sensu Reimer et al. (2013). Calibrated ages are presented at the $2 \sigma$ confidence interval 
Like any other scientific method, radiocarbon has developed in fits and starts and is subject to human and systematic errors. Modern protocols for handling, processing, and analyzing samples have evolved from the early days. Such an evolution is the product of trial and error conducted with real samples over decades. This requires modern and future archaeologists to approach legacy data with care and knowledge of potential errors that may have occurred. It does not mean that all radiocarbon dates that do not involve AMS are intrinsically flawed.

Significant Wiggles and Plateaus in the Radiocarbon Calibration Curve Occur at Key Moments in African Prehistory

All archaeologists must contend with inherent imprecisions in the calibration curve converting atmospheric concentrations of ${ }^{14} \mathrm{C}$ into a calendar ages. Significant "wiggles" in the radiocarbon calibration curve confound precise archaeological understandings of the timing of significant milestones in human cultural evolution. Variability in ${ }^{14} \mathrm{C}$ production in the atmosphere produces wiggles in the calibration curve, which create a circumstance whereby one radiocarbon date corresponds to multiple calendar ages. Furthermore, discontinuities in the ${ }^{14} \mathrm{C}$ calibration curve between atmospheric and marine reservoirs imply higher levels of ${ }^{14} \mathrm{C}$ in the oceans compared to atmosphere between 34,000 and 40,000 years ago. This is logically counterintuitive but nevertheless seems to have occurred (Bronk Ramsey et al. 2013).

The transition from Middle Stone Age (or Middle Paleolithic) to Later Stone Age (or Upper Paleolithic) technological complexes in Africa and Eurasia are predicated on radiocarbon ages. However, there remain periods of high statistical uncertainty in calibrating ${ }^{14} \mathrm{C}$ ages to calendar years before present. Until the publication of the latest calibration curve in 2013 based on varved sediments from Lake Suigetsu, Japan, imprecision was on the order of multiple centuries before 14,000 years ago for most ${ }^{14} \mathrm{C}$ ages, even those run by AMS methods (Bronk Ramsey et al. 2013). Even today, though, imprecision is on the order of multiple decades to centuries, assuming that the sample taphonomy was pristine (Reimer et al. 2013).
Fig. 5 Calibrated radiocarbon age of $2200 \pm 10{ }^{14} \mathrm{C}$ years $\mathrm{BP}$ using the CALIB 6.0 software (Reimer et al. 2013)

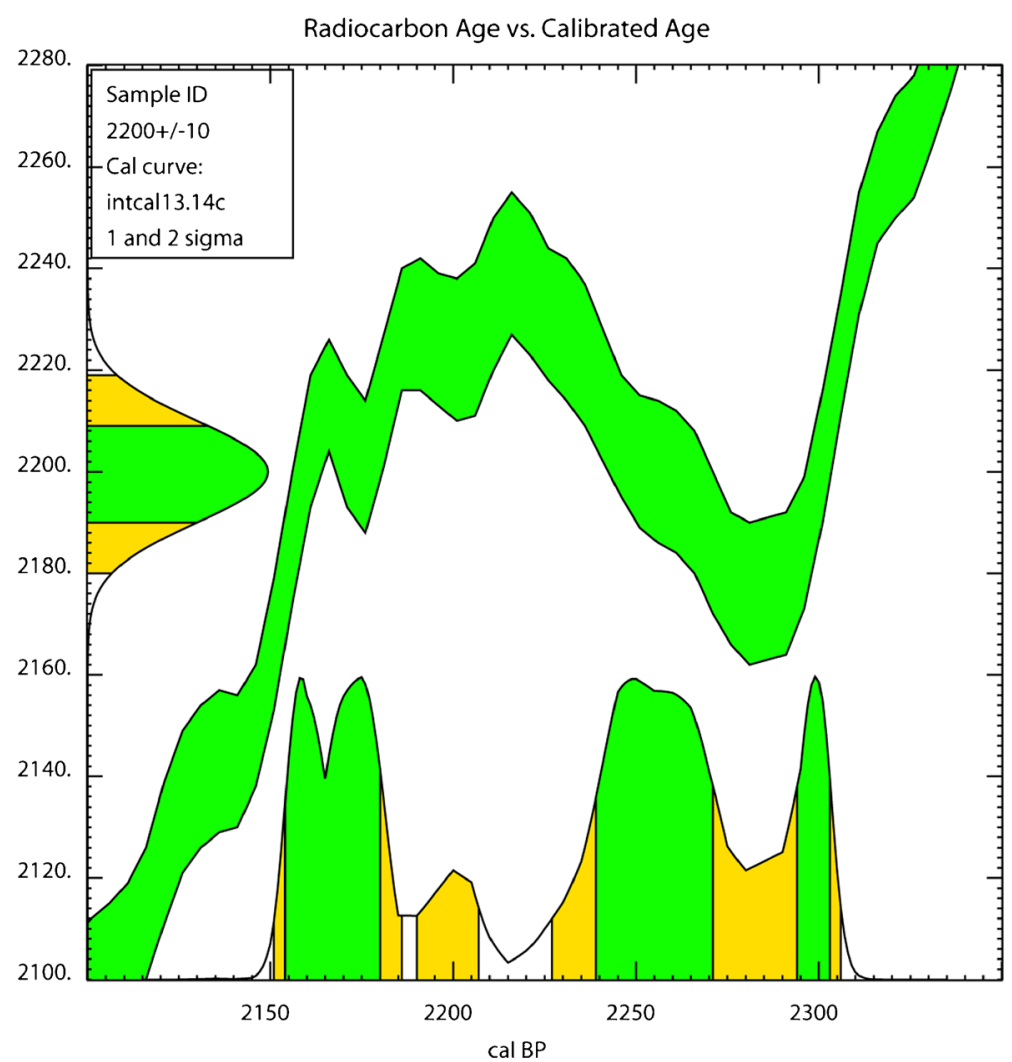


Similarly, "plateaus" (Bronk Ramsey et al. 2001) or flatlines in the calibration curve seem to occur at inconvenient times for dating major cultural milestones in Africa. This can result in decadal to century-scale overlaps in the calibration, particularly between 2400 and $2700{ }^{14} \mathrm{C}$ years BP (2400 and 2790 cal. years BP) and a multidecadal reversal in the atmospheric ${ }^{14} \mathrm{C}$ reservoir centered around $3300{ }^{14} \mathrm{C}$ years BP (ca. 3500 cal. years BP; Reimer et al. 2013). These dates correlate to the earliest evolution and spread of food production techniques (including animal pastoralism and plant cultivation) throughout much of sub-Saharan Africa.

An arbitrarily entered radiocarbon age of $2200 \pm 10$ ${ }^{14} \mathrm{C}$ years BP calibrates to $2150-2310$ cal. years BP (Fig. 5), demonstrating another such period of relative imprecision. This dates to the time when yam (Dioscorea bulbifera) and pearl millet (Pennisetum glaucum) cultivators who spoke Bantu languages began to trickle into eastern Africa (Barham and Mitchell 2008; Ehret 1998, 2001; Phillipson 2005). Archaeologists and linguists have expended a lot of ink trying to disentangle whether iron working, farming and Bantu languages entered eastern Africa as a package or as separate features of a new economy (e.g., Kusimba and Kusimba 2005; Lane et al. 2007; Phillipson 2002; Vansina 1995). The inherent trouble with solving the riddle involves the imprecision of the radiocarbon calibration curve at this time (Killick 2004).

Another significant plateau occurs after AD 1620 in the form of the Suess Effect (Keeling 1979). For Africanists, this plateau is particularly unfortunate as it occurs during the onset of European colonization, transatlantic slave trade, warfare and depopulation in the southern and western African interiors, and the introduction of domesticates from the Americas. Additionally, the transition of global climates from the Little Ice Age (AD 1300-1870) to the current climate regime falls within this range. At the moment, there is no correction for the Suess Effect. Given the patchy nature of historical records from the African continent prior to the twentieth century, this particular plateau significantly inhibits understanding the evolution of modern African cultural and ecological systems.

\section{Conclusion}

The use of radiocarbon dating techniques has justifiably proliferated in recent decades in archaeological research, but there remains significant potential for the inclusion of random and systematic errors in reporting the results. Carbon reservoirs and recycled organic remains can inflate the apparent age of samples. Diagenesis of carbon isotopes from artifacts recovered within pervasive hot and humid climate conditions, and from archived collections, tends to provide age underestimates; microorganisms attack and replace carbon produced metabolically during an organism's lifetime with more modern carbon. The use of legacy radiocarbon ages must be carefully considered, and calibration of absolute ages from ${ }^{14} \mathrm{C}$ ages lacks precision during certain significant periods of African prehistory.

Since it remains one of the most precise methods of radiometric dating, there is a temptation for archaeologists to use radiocarbon chronologies uncritically, and without secondary, more expensive and less precise methods of testing a site's age of occupation. However, the investment in multiple methods allows archaeologists to build both an accurate and a precise geochronology. Archaeologists must become more conversant in the range of options for dating at their disposal, and structure multiple methods to test site formation models into the proposal phase of every project.

Given the realities of the archaeological record we have and want to improve upon, I advocate that archaeologists engage in four simple mental exercises before writing a proposal or publishing data generated from an archaeological project. This list is not comprehensive, but...

(1) Know the materials you are dating. What are the inherent metabolic and taphonomic features of the organisms you are dating that could impact the accuracy of your sample? What did the organism consume? Is there potential that old carbon can be present in the organism based on the ecology of the animal? Is there potential for postmortem diagenetic effects where carbon is exchanged between the dead organism and the environment? Using tools like FTIR, SEM, or developing a protocol for testing, the carbon reservoir in shell prior to dating minimizes the chances for obtaining spurious results.

(2) Similarly, consider the potential that people may have conserved certain types of artifacts over multiple generations. Remains like annual seeds are far less likely to have been recycled than bark from a tree. However, seeds suffer from postdepositional 
vertical movement in the profile more so than a big chunk of wood, so stratigraphic context is critical.

(3) When using legacy data, be aware of inherent issues that may have produced inaccurate results beyond the published precision of the ages. Labs have had varying quality and rigor in running standards and should not be treated equally. The journal Radiocarbon publishes the results of interlaboratory evaluations, both sanctioned and unsanctioned, on a regular basis (e.g., Kim et al. 2016; Scott et al. 2010). The results are anonymous, but it is worth having a discussion with a laboratory you are considering using about their participation in such tests and what the results demonstrated. Such a conversation highlights the importance of accurate results to the laboratory and improves the chances of obtaining the best geochronology possible.

(4) Using multiple dating methods and obtaining multiple dates is strongly advocated. In particular, OSL can provide accurate estimates of depositional contexts, especially when used in conjunction with AMS ${ }^{14} \mathrm{C}$ dating. Uranium-series, argon-argon, and paleomagnetic and terrestrial cosmogenic nuclide ages can also be used to calibrate the accuracy of your radiocarbon dates (Wright 2017); however, radiocarbon dating remains the most versatile dating method available in our archaeological toolkit.

\begin{abstract}
Acknowledgements This work was supported by the National ResearchFoundation ofKorea funded by the Korean Government (NRF-2013S1A5B6043901 and NRF-2013S1A5A8021512). Stanley Ambrose generously offered keen insights into dolomitization and other aspects of this paper. This manuscript was produced from a paper read at the Society of American Archaeologists' 80th Annual Conference session entitled "Issues in Building Radiocarbon Chronologies." Many thanks to my session coorganizers Jangsuk Kim, Colin Grier, and Andrew Martindale for stimulating conversations and support. Thank you to Cory-Alice Andre-Johnson for her translation of the abstract into French. Three anonymous reviewers and the steady editorial hand of Adria LaViolette greatly improved the quality of this manuscript, and I extend a heartfelt debt of gratitude for their constructive comments and criticisms.
\end{abstract}

\section{Compliance with Ethical Standards}

Funding This study was funded by the National Research Foundation of Korea (NRF-2013S1A5B6043901 and NRF2013S1A5A8021512).

Conflict of Interest The author declares that he has no conflict of interest.
Open Access This article is distributed under the terms of the Creative Commons Attribution 4.0 International License (http:// creativecommons.org/licenses/by/4.0/), which permits unrestricted use, distribution, and reproduction in any medium, provided you give appropriate credit to the original author(s) and the source, provide a link to the Creative Commons license, and indicate if changes were made.

\section{References}

Ambers, J. C., Leese, M. N., \& Bowman, S. E. (1986). Detection of bias in the background of vials used for scintillation counting. Radiocarbon, 28(2A), 586-591.

Ambrose, S. H. (1990). Preparation and characterization of bone and tooth collagen for isotopic analysis. Journal of Archaeological Science, 17(4), 431-451.

Ambrose, S. H. (1998). Chronology of the Later Stone Age and food production in East Africa. Journal of Archaeological Science, 25, 377-392.

Ambrose, S. H., \& DeNiro, M. J. (1986a). The isotopic ecology of East African mammals. Oecologia, 69(3), 395-406.

Ambrose, S. H., \& DeNiro, M. J. (1986b). Reconstruction of African human diet using bone collagen carbon and nitrogen isotope ratios. Nature, 319, 321-324.

Ambrose, S. H., \& Krigbaum, J. (2003). Bone chemistry and bioarchaeology. Journal of Anthropological Archaeology, 22, 193-199.

Amundson, R., Wang, Y., Chadwick, O., Trumbore, S., McFadden, L., McDonald, E., Wells, S., \& DeNiro, M. (1994). Factors and processes governing the $14 \mathrm{C}$ content of carbonate in desert soils. Earth and Planetary Science Letters, 125(1-4), 385-405.

Aravena, R., Warner, B. G., MacDonald, G. M., \& Hanf, K. I. (1992). Carbon isotope composition of lake sediments in relation to lake productivity and radiocarbon dating. Quaternary Research, 37(3), 333-345.

Arnold, J. R. (1954). Scintillation counting of natural radiocarbon: I. The counting method. Science, 119(3083), 155-157.

Barham, L., \& Mitchell, P. M. (2008). The first Africans: African archaeology from the earliest toolmakers to most recent foragers. Cambridge: University of Cambridge Press.

Bateman, M. D., Carr, A. S., Murray-Wallace, C. V., Roberts, D. L., \& Holmes, P. J. (2008). A dating intercomparison study on Late Stone Age coastal midden deposits, South Africa. Geoarchaeology, 23(6), 715-741.

Bayliss, A. (2009). Rolling out revolution: Using radiocarbon dating in archaeology. Radiocarbon, 51(1), 123-147.

Bird, M. I., Fifield, L. K., Santos, G. M., Beaumont, P. B., Zhou, Y., di Tada, M. L., \& Hausladen, P. A. (2003). Radiocarbon dating from 40 to $60 \mathrm{ka} \mathrm{BP}$ at Border Cave, South Africa. Quaternary Science Reviews, 22(8-9), 943-947.

Boaretto, E. (2009). Dating materials in good archaeological contexts: The next challenge for radiocarbon analysis. Radiocarbon, 51(1), 275-281.

Bower, J. R. F. (1991). The pastoral Neolithic of East Africa. Journal of World Prehistory, 5, 49-82.

Bowman, S. E., Ambers, J. C., \& Leese, M. N. (1990). Reevaluation of British Museum radiocarbon dates issued between 1980 and 1984. Radiocarbon, 32(1), 59-79. 
Brock, F., Higham, T. F. G., Ditchfield, P., \& Bronk Ramsey, C. (2010). Current pretreatment methods for AMS radiocarbon dating at the Oxford Radiocarbon Accelerator Unit (ORAU). Radiocarbon, 52(1), 103-112.

Brock, F., Wood, R., Higham, T. F. G., Ditchfield, P., Bayliss, A., \& Ramsey, C. B. (2012). Reliability of nitrogen content $(\% \mathrm{~N})$ and carbon:nitrogen atomic ratios $(\mathrm{C}: \mathrm{N})$ as indicators of collagen preservation suitable for radiocarbon dating. Radiocarbon, 54(3-4), 879-886.

Bronk Ramsey, C. (2008). Radiocarbon dating: Revolutions in understanding. Archaeometry, 50(2), 249-275.

Bronk Ramsey, C., van der Plicht, J., \& Weninger, B. (2001). "Wiggle matching" radiocarbon dates. Radiocarbon, 43(2; PART A), 381-390.

Bronk Ramsey, C., Scott, M., \& van der Plicht, H. (2013). Calibration for archaeological and environmental terrestrial samples in the time range $26-50 \mathrm{ka}$ cal BP. Radiocarbon, 55(4), 2021-2027.

Chappell, J., \& Polach, H. A. (1972). Some effects of partial recrystallisation on $14 \mathrm{C}$ dating Late Pleistocene corals and molluscs. Quaternary Research, 2(2), 244-252.

Chen, Y., \& Polach, H. (1986). Validity of $14 \mathrm{C}$ ages of carbonates in sediments. Radiocarbon, 28(2A), 464-472.

Clist, B. (2012). Vers une réduction des préjugés et la fonte des antagonismes: un bilan de l'expansion de la métallurgie du fer en Afrique sud-saharienne. Journal of African Archaeology, 10(1), 71-84.

Close, A. E. (1988). Current research and recent radiocarbon dates from northern Africa, III. The Journal of African History, 29(02), 145-176.

Cohen, A. S., Talbot, M. R., Awramik, S. M., Dettman, D. L., \& Abell, P. (1997). Lake level and paleoenvironmental history of Lake Tanganyika, Africa, as inferred from late Holocene and modern stromatolites. Geological Society of America Bulletin, 109(4), 444-460.

Collett, D., \& Robertshaw, P. (1983). Problems in the interpretation of radiocarbon dates: The pastoral Neolithic of East Africa. African Archaeological Review, 1, 57-74.

Cook, G. T., Bonsall, C., Hedges, R. E. M., McSweeney, K., Boronean, V., \& Pettitt, P. B. (2001). A freshwater dietderived $14 \mathrm{C}$ reservoir effect at the Stone Age sites in the Iron Gates gorge. Radiocarbon, 43(Article), 453-460.

Cook, G. T., Bonsall, C., Hedges, R. E. M., McSweeney, K., Boronean, V., Bartosiewicz, L., \& Pettitt, P. B. (2002). Problems of dating human bones from the Iron Gates. Antiquity, 76(291), 77-85.

Courtney Mustaphi, C., \& Marchant, R. (2016). A database of radiocarbon dates for palaeoenvironmental research in eastern Africa. Open Quaternary, 2, 3.

Creel, D., \& Long, A. (1986). Radiocarbon dating of corn. American Antiquity, 51(4), 826-837.

Dal Sasso, G., Maritan, L., Usai, D., Angelini, I., \& Artioli, G. (2014). Bone diagenesis at the micro-scale: Bone alteration patterns during multiple burial phases at Al Khiday (Khartoum, Sudan) between the Early Holocene and the II century AD. Palaeogeography, Palaeoclimatology, Palaeoecology, 416, 30-42.

De Caluwé, E., De Smedt, S., Assogbadjo, A. E., Samson, R., Sinsin, B., \& Van Damme, P. (2009). Ethnic differences in use value and use patterns of baobab (Adansonia digitata L.) in northern Benin. African Journal of Ecology, 47(3), 433-440.
D’Elia, M., Gianfrate, G., Quarta, G., Giotta, L., Giancane, G., \& Calcagnile, L. (2007). Evaluation of possible contamination sources in the $14 \mathrm{C}$ analysis of bone samples by FTIR spectroscopy. Radiocarbon, 49(2), 201-210.

deMenocal, P., Ortiz, J., Guilderson, T., Adkins, J., Sarnthein, M., Baker, L., \& Yarusinsky, M. (2000). Abrupt onset and termination of the African Humid Period: Rapid climate responses to gradual insolation forcing. Quaternary Science Reviews, 19(1-5), 347-361.

Dewar, G., Reimer, P. J., Sealy, J., \& Woodborne, S. (2012). LateHolocene marine radiocarbon reservoir correction $(\Delta \mathrm{R})$ for the west coast of South Africa. The Holocene, 22(12), 14811489.

Driessens, F. C. M., \& Verbeeck, R. M. H. (1990). Biominerals. Boca Raton: CRC Press.

Ehret, C. (1998). An African Classical age: Eastern and southern Africa in world history, 1000 BC to AD 400. Charlottesville: University Press of Virginia.

Ehret, C. (2001). Bantu expansions: Re-envisioning a central problem of early African history. The International Journal of African Historical Studies, 34(1), 5-41.

Forman, S. L., Wright, D. K., \& Bloszies, C. (2014). Variations in water level for Lake Turkana in the past 8500 years near Mt. Porr, Kenya and the transition from the African Humid Period to Holocene aridity. Quaternary Science Reviews, 97, 84-101.

Freundlich, J. C., Kuper, R., Breunig, P., \& Bertram, H. G. (1989). Radiocarbon dating of ostrich eggshells. Radiocarbon, 31(3), 1030-1034.

Gasse, F. (2000). Hydrological changes in the African tropics since the Last Glacial Maximum. Quaternary Science Reviews, 19(1-5), 189-211.

Gauthier, C., \& Hatté, C. (2008). Effects of handling, storage, and chemical treatments on $\delta 13 \mathrm{C}$ values of terrestrial fossil organic matter. Geochemistry, Geophysics, Geosystems, 9(8), Q08011. doi:10.1029/2008GC001967.

Geyh, M. A. (1990). Radiocarbon dating problems using acetylene as counting gas. Radiocarbon, 32(2), 321-324.

Goslar, T., \& Pazdur, M. F. (1985). Contamination studies on mollusk shell samples. Radiocarbon, 27(1), 33-42.

Halfman, J. D., Jacobson, D. F., Cannela, C. M., Haberyan, K. A., \& Finney, B. P. (1992). Fossil diatoms and the mid to late Holocene paleolimnology of Lake Turkana, Kenya: A reconnaissance study. Journal of Paleolimnology, 7(1), 23-35.

Halfman, J. D., Johnson, T. C., \& Finney, B. P. (1994). New AMS dates, stratigraphic correlations and decadal climatic cycles for the past 4-ka at Lake Turkana, Kenya. Palaeogeography Palaeoclimatology Palaeoecology, 111(1-2), 83-98.

Haynes, C. V., Eyles, C. H., Pavlish, L. A., Ritchie, J. C., \& Rybak, M. (1989). Holocene palaeoecology of the eastern Sahara; Selima Oasis. Quaternary Science Reviews, 8, 109-136.

Hedges, R. E. M. (2002). Bone diagenesis: An overview of processes. Archaeometry, 44(3), 319-328.

Higham, T. F. G. (2011). European Middle and Upper Palaeolithic radiocarbon dates are often older than they look: Problems with previous dates and some remedies. Antiquity, 85(327), 235-249.

Higham, T. F. G., Jacobi, R. M., \& Ramsey, C. B. (2006). AMS radiocarbon dating of ancient bone using ultrafiltration. Radiocarbon, 48(2), 179. 
Hird, K., \& Tucker, M. E. (1988). Contrasting diagenesis of two carboniferous oolites from South Wales: A tale of climatic influence. Sedimentology, 35(4), 587-602.

Hodder, I. (1977). The distribution of material culture: Items in the Baringo District, western Kenya. Man, 12(2), 239-269.

Hollund, H. I., Ariese, F., Fernandes, R., Jans, M. M. E., \& Kars, H. (2013). Testing an alternative high-throughput tool for investigating bone diagenesis: FTIR in attenuated total reflection (ATR) mode. Archaeometry, 55(3), 507-532.

Hua, Q., Webb, G. E., Zhao, J.-X., Nothdurft, L. D., Lybolt, M., Price, G. J., \& Opdyke, B. M. (2015). Large variations in the Holocene marine radiocarbon reservoir effect reflect ocean circulation and climatic changes. Earth and Planetary Science Letters, 422, 33-44.

IGBP-DIS (1998). SoilData(V.0) A program for creating global soilproperty databases. https://nelson.wisc.edu/sage/data-andmodels/datasets.php. France: IGBP Global Soils Data Task.

International Study Group. (1982). An inter-laboratory comparison of radiocarbon measurements in tree rings. Nature, 298(5875), 619-623.

Jain, S., Bajpai, S., Kumar, G., \& Pruthi, V. (2016). Microstructure, crystallography and diagenetic alteration in fossil ostrich eggshells from Upper Palaeolithic sites of Indian peninsular region. Micron, 84, 72-78.

Jans, M. M. E. (2008). Microbial bioerosion of bone-A review. In M. Wisshak \& L. Tapanila (Eds.), Current developments in bioerosion (pp. 397-413). Berlin Heidelberg: SpringerVerlag.

Janz, L., Feathers, J. K., \& Burr, G. S. (2015). Dating surface assemblages using pottery and eggshell: Assessing radiocarbon and luminescence techniques in Northeast Asia. Journal of Archaeological Science, 57, 119-129.

Jull, A. J. T., Burr, G. S., \& Hodgins, G. W. L. (2013). Radiocarbon dating, reservoir effects, and calibration. Quaternary International, 299, 64-71.

Kazimierz, R., Willibald, S., Roberto, G., Scott, E. M., Beukens, R. P., Bernd, K., \& van der Plicht, J. (1992). The IAEA 14C intercomparison exercise 1990. Radiocarbon, 34, 506-519.

Keeling, C. D. (1979). The Suess effect: 13Carbon-14Carbon interrelations. Environment International, 2(4), 229-300.

Killick, D. J. (2004). Review essay. What do we know about African iron working? Journal of African Archaeology, 2(1), 97-112.

Killick, D. J., van der Merwe, N. J., Gordon, R. B., \& Grébénart, D. (1988). Reassessment of the evidence for early metallurgy in Niger, West Africa. Journal of Archaeological Science, 15(4), 367-394.

Kim, J., Wright, D. K., Lee, Y., Lee, J., Choi, S., Kim, J., Ahn, S. M., Choi, J., Seong, C., Hyun, C. H., Hwang, J., Yang, H., \& Yang, J. (2016). AMS dates from two archaeological sites of Korea: Blind tests. Radiocarbon, 58(1), 115-130.

Kromer, B., \& Münnich, K. O. (1992). $\mathrm{CO}_{2}$ gas proportional counting in radiocarbon dating-Review and perspective. In R. E. Taylor, A. Long, \& R. S. Kra (Eds.), Radiocarbon after four decades (pp. 184-197). New York: Springer.

Kusimba, C. M., \& Kusimba, S. B. (2005). Mosaics and interactions: East Africa, $2000 \mathrm{BP}$ to the present. In A. B. Stahl (Ed.), African archaeology: A critical introduction (pp. 392419). Malden, MA: Blackwell Publishing.

Lane, P., Ashley, C., Seitsonen, O., Harvey, P., Mire, S., \& Odede, F. (2007). The transition to farming in eastern Africa: New faunal and dating evidence from Wadh Lang'o and Usenge, Kenya. Antiquity, 81(1), 62-81.

Lawal, B. (1973). Dating problems at Igbo-Ukwu. Journal of African History, 14(1), 1-8.

Lebon, M., Reiche, I., Bahain, J. J., Chadefaux, C., Moigne, A. M., Fröhlich, F., Sémah, F., Schwarcz, H. P., \& Falguères, C. (2010). New parameters for the characterization of diagenetic alterations and heat-induced changes of fossil bone mineral using Fourier transform infrared spectrometry. Journal of Archaeological Science, 37(9), 2265-2276.

Lee-Thorp, J. A. (2008). On isotopes and old bones. Archaeometry, 50(6), 925-950.

Lehto, J., \& Hou, X. (2011). Chemistry and analysis of radionuclides: Laboratory techniques and methodology. New York: John Wiley \& Sons.

López-Costas, O., Lantes-Suárez, Ó., \& Martínez Cortizas, A. (2016). Chemical compositional changes in archaeological human bones due to diagenesis: Type of bone vs soil environment. Journal of Archaeological Science, 67, 43-51.

Marom, A., McCullagh, J. S. O., Higham, T. F. G., \& Hedges, R. E. M. (2013). Hydroxyproline dating: Experiments on the $14 \mathrm{C}$ analysis of contaminated and low-collagen bones. Radiocarbon, 55(2-3), 698-708.

Marty, J., \& Myrbo, A. (2014). Radiocarbon dating suitability of aquatic plant macrofossils. Journal of Paleolimnology, 52(4), 435-443.

Maurer, A. F., Person, A., Tütken, T., Amblard-Pison, S., \& Ségalen, L. (2014). Bone diagenesis in arid environments: An intraskeletal approach. Palaeogeography, Palaeoclimatology, Palaeoecology, 416, 17-29.

Mitchell, P., \& Whitelaw, G. (2005). The archaeology of southernmost Africa from c. $2000 \mathrm{BP}$ to the early 1800s: A review of recent research. Journal of African History, 46(2), 209-241.

Mollenhauer, G., Inthorn, M., Vogt, T., Zabel, M., Sinninghe Damsté, J. S., \& Eglinton, T. I. (2007). Aging of marine organic matter during cross-shelf lateral transport in the Benguela upwelling system revealed by compound-specific radiocarbon dating. Geochemistry, Geophysics, Geosystems, 8(9), 10.1029/2007GC001603.

National Oceanic and Atmospheric Administration (2008). Coastal Currents. http://oceanservice.noaa. gov/education/kits/currents/03coastal4.html2016. Accessed 24 Nov 2016.

Neulieb, T., Levac, E., Southon, J., Lewis, M., Pendea, I. F., \& Chmura, G. L. (2013). Potential pitfalls of pollen dating. Radiocarbon, 55(2-3), 1142-1155.

Nkana, Z. G., \& Iddi, S. (1991). Utilization of Baobab (Adansonia digitata) in Kondoa District, Central Tanzania (Vol. 50). Morogoro, Tanzania: Faculty of Forestry, Sokoine University of Agriculture.

Olsen, J., Heinemeier, J., Lübke, H., Lüth, F., \& Terberger, T. (2010). Dietary habits and freshwater reservoir effects in bones from a Neolithic NE German cemetery. Radiocarbon, 52(3), 635.

Pachur, H. J., \& Hoelzmann, P. (2000). Late Quaternary palaeoecology and palaeoclimates of the eastern Sahara. Journal of African Earth Sciences, 30(4), 929-939.

Patrut, A., Reden, K. F., Pelt, R., Mayne, D. H., Lowy, D. A., \& Margineanu, D. (2011). Age determination of large live trees with inner cavities: Radiocarbon dating of Platland tree, a giant African baobab. Annals of Forest Science, 68(5), 993-1003. 
Patrut, A., Woodborne, S., von Reden, K. F., Hall, G., Hofmeyr, M., Lowy, D. A., \& Patrut, R. T. (2015). African baobabs with false inner cavities: The radiocarbon investigation of the Lebombo Eco Trail baobab. PloS One, 10(1), e0117193.

Philippsen, B. (2013). The freshwater reservoir effect in radiocarbon dating. Heritage Science, 1(1), 1-24.

Phillipson, D. W. (2002). Language and farming dispersals in subSaharan Africa, with particular reference to the Bantuspeaking peoples. In P. Bellwood \& C. Renfrew (Eds.), Examining the farming/language dispersal hypothesis (pp. 177-187). Cambridge: University of Cambridge Press.

Phillipson, D. W. (2005). African archaeology. Cambridge: Cambridge University Press.

Polach, H. A. (1987). Evaluation and status of liquid scintillation counting for radiocarbon dating. Radiocarbon, 29(1), 1-11.

Polach, H. A. (1992). Four decades of progress in 14C dating by liquid scintillation counting and spectrometry. In R. E. Taylor, A. Long, \& R. S. Kra (Eds.), Radiocarbon after four decades: An interdisciplinary perspective (pp. 198-213). New York, NY: Springer New York.

Rapp, G., \& Hill, C. L. (2006). Geoarchaeology (2nd ed.). New Haven: Yale University Press.

Reimer, P. J., Baillie, M. G. L., Bard, E., Bayliss, A., Beck, J. W., Bertrand, C., et al. (2004a). IntCal04 terrestrial radiocarbon age calibration, 0-26 Cal Kyr BP. Radiocarbon, 46, 1029-1058.

Reimer, P. J., Brown, T. A., \& Reimer, R. W. (2004b). Discussion: Reporting and calibration of post-bomb ${ }^{14} \mathrm{C}$ data. Radiocarbon, 46(3), 1299-1304.

Reimer, P. J., Bard, E., Bayliss, A., Beck, J. W., Blackwell, P. G., Bronk Ramsey, C., et al. (2013). IntCal13 and Marine13 radiocarbon age calibration curves $0-50,000$ years cal BP. Radiocarbon, 55(4), 1869-1887.

Rick, T. C., Vellanoweth, R. L., \& Erlandson, J. M. (2005). Radiocarbon dating and the "old shell" problem: Direct dating of artifacts and cultural chronologies in coastal and other aquatic regions. Journal of Archaeological Science, 32(11), 1641-1648.

Schiffer, M. B. (1982). Hohokam chronology: An essay on history and method. In R. H. McGuire \& M. B. Schiffer (Eds.), Hohokam and Patayan: Prehistory of southwestern Arizona (pp. 299-344). New York: Academic Press.

Schiffer, M. B. (1986). Radiocarbon dating and the "old wood" problem: The case of the Hohokam chronology. Journal of Archaeological Science, 13(1), 13-30.

Schmidt, M. (2000). Radiocarbon dating New Zealand prehistory using marine shell. BAR International Series 842. Oxford: British Archaeological Reports.

Schumann, K., Wittig, R., Thiombiano, A., Becker, U., \& Hahn, K. (2012). Uses, management, and population status of the baobab in eastern Burkina Faso. Agroforestry Systems, 85(2), 263-278.

Scott, E. M., Bryant, C., Cook, G. T., \& Naysmith, P. (2003). Is there a Fifth International Radiocarbon Intercomparison (VIRI)? Radiocarbon, 45(3), 493-495.

Scott, E. M., Cook, G., \& Naysmith, P. (2010). The Fifth International Radiocarbon Intercomparison (VIRI): An assessment of laboratory performance in stage 3 . Radiocarbon, 53(2-3), 859-865.

Sinclair, P. J. J. (1991). Archaeology in eastern Africa: An overview of current chronological issues. Journal of African History, 32, 179-219.

Snoeck, C., Lee-Thorp, J. A., \& Schulting, R. J. (2014). From bone to ash: Compositional and structural changes in burned modern and archaeological bone. Palaeogeography, Palaeoclimatology, Palaeoecology, 416, 55-68.

Stafford, T., Jull, A. J. T., Brendel, K., Duhamel, R. C., \& Donahue, D. (1987). Study of bone radiocarbon dating accuracy at the University of Arizona NSF accelerator facility for radioisotope analysis. Radiocarbon, 29(1), 24- 44.

Stoller, P. (2003). Circuits of African art/paths of wood: Exploring an anthropological trail. Anthropological Quarterly, 76(2), 207-234.

Stuiver, M., \& Polach, H. A. (1977). Reporting of ${ }^{14} \mathrm{C}$ data. Radiocarbon, 19(3), 355-363.

Swart, P. K., Berier, D., McNeill, D., Guzikowski, M., Harrison, S. A., \& Dedick, E. (1989). Interstitial water geochemistry and carbonate diagenesis in the sub-surface of a Holocene mud island in Florida Bay. Bulletin of Marine Science, 44(1), 490-514.

Taylor, R. E. (1992). Radiocarbon dating of bone: To collagen and beyond. In R. E. Taylor, A. Long, \& R. S. Kra (Eds.), Radiocarbon after four decades: An interdisciplinary perspective (pp. 375-402). New York: Springer New York.

Taylor, R. E., \& Bar-Yosef, O. (2014). Radiocarbon dating: An archaeological perspective. Walnut Creek, CA: Left Coast Press.

Thomas, D. S. G., \& Burrough, S. L. (2012). Interpreting geoproxies of late Quaternary climate change in African drylands: Implications for understanding environmental change and early human behaviour. Quaternary International, 253, 5-17.

Trueman, C. N. G., Behrensmeyer, A. K., Tuross, N., \& Weiner, S. (2004). Mineralogical and compositional changes in bones exposed on soil surfaces in Amboseli National Park, Kenya: Diagenetic mechanisms and the role of sediment pore fluids. Journal of Archaeological Science, 31(6), 721-739.

University of East Anglia (2016). Climate research unit, precipitation data. https://nelson.wisc.edu/sage/data-andmodels/datasets.php: IGBP-DIS. Accessed 24 Nov 2016.

van Klinken, G. J. (1999). Bone collagen quality indicators for palaeodietary and radiocarbon measurements. Journal of Archaeological Science, 26(6), 687-695.

Vansina, J. (1995). New linguistic evidence and "the Bantu 'expansion.” Journal of African History, 36(2), 173-195.

Vogel, J. C., Visser, E., \& Fuls, A. (2001). Suitability of ostrich eggshell for radiocarbon dating. Radiocarbon, 43(1), 133-137.

Wagner, G. A. (1998). Age determination of young rocks and artifacts: Physical and chemical clocks in Quaternary geology and archaeology. New York: Springer Science \& Business Media.

Waters, M. R. (1998). Principles of geoarchaeology: A North American perspective. Tucson: University of Arizona Press.

Wohlfarth, B., Skog, G., Possnert, G., \& Holmquist, B. (1998). Pitfalls in the AMS radiocarbon-dating of terrestrial macrofossils. Journal of Quaternary Science, 13(2), 137-145.

Woodburn, J. (1970). Hunters and gatherers: The material culture of the Nomadic Hadza. London: The British Museum.

Wright, D. K. (2017). Other radiometric dating techniques (within chapter 5: Ecofacts and related studies). In A. L. Smith, E. Cornelissen, O. Gosselain, \& S. MacEachern (Eds.), African archaeology field manual/Manuel de terrain en archéologie Africaine (pp. 35-40). Brussels: Royal Museum for Central Africa.

Wright, D. K., Forman, S. L., Kiura, P., Bloszies, C., \& Beyin, A. (2015). Lakeside view: Sociocultural responses to changing water levels of Lake Turkana, Kenya. African Archaeological Review, 32(2), 335-367. 
Wündsch, M., Haberzettl, T., Meadows, M. E., Kirsten, K. L., Kasper, T., Baade, J., Daut, G., Stoner, J. S., \& Mäusbacher, R. (2016). The impact of changing reservoir effects on the 14C chronology of a Holocene sediment record from South Africa. Quaternary Geochronology, 36, 148-160.

Yates, T. J. S., Spiro, B. F., \& Vita-Finzi, C. (2002). Stable isotope variability and the selection of terrestrial mollusc shell samples for 14C dating. Quaternary International, 87(1), 87-100.

Zamanian, K., Pustovoytov, K., \& Kuzyakov, Y. (2016). Pedogenic carbonates: Forms and formation processes. Earth-Science Reviews, 157, 1-17.
Zangato, É., \& Holl, A. F. C. (2010). On the iron front: New evidence from North-Central Africa. Journal of African Archaeology, 8(1), 7-23.

Zazzo, A. (2014). Bone and enamel carbonate diagenesis: A radiocarbon prospective. Palaeogeography, Palaeoclimatology, Palaeoecology, 416, 168-178.

Zazzo, A., \& Saliège, J. F. (2011). Radiocarbon dating of biological apatites: A review. Palaeogeography, Palaeoclimatology, Palaeoecology, 310(1-2), 52-61. 